\title{
Docking and Integration of ERP Audit Experiment Teaching and ERP Sand Table Simulation Experiment
}

\author{
Jiang Lingling, a , Wang Yumeng ${ }^{2, b}$ \\ ${ }^{1}$ Harbin University of Commerce, 150028, China \\ ${ }^{2}$ Harbin University of Commerce, 150028, China \\ a, bjyn7777@sina.com
}

Keywords: ERP audit experiment; ERPS sand table; Simulation docking integration

\begin{abstract}
Based on the demand of talents in modern enterprises, this paper analyzes the feasibility of docking and integration of sandbox simulation experiment and audit experiment in ERP environment, and proposes the path of experimental curriculum resource integration to realize ERP sandbox simulation experiment resources. Second development, effective integration with ERP audit experiments, training risk-conscious enterprise management talents.
\end{abstract}

\section{Introduction}

ERP is an important means and method for enterprises to improve their management level. Each management function includes integration, coordination and systemization of accounting, production, sales and human resources, real-time coordination and intensive management mode and business process. Governing. The ERP sandbox simulation experiment allows each student to act as a "corporate manager". Participants are given different roles, based on market demand, market forecasts, and developing and implementing the company's R\&D, production, sales, investment and financing. The strategy forms different business operation management cases, which provides a wealth of case resources for the ERP audit lab. Under the premise of ERP sandbox simulation experiment, we can carry out auditing experiment teaching based on ERP environment and planning around ERP system, so that students can not only be familiar with the internal audit process, but also feel the position of internal audit in the entire economic control chain. And function, timely understand and learn advanced enterprise management ideas and management models, fully appreciate the value-added services brought by internal audit to enterprises.

\section{Necessity and feasibility of docking and integration of ERP sand table simulation training and ERP risk management auditing experiment}

\subsection{ERP audit experiment teaching reform is to meet the needs of talents in modern enterprise risk management audit.}

With the establishment of the modern enterprise system, the market competition is extremely fierce, and the scope of risks faced by enterprises has been greatly expanded. Internal audit should be based on the needs of the company's operation and management, to strengthen the company's internal control management, improve the company's risk prevention and overall benefits as the goal. The audit work is changed from error prevention to performance-based and risk-based audit. Internal audit should be transformed into internal control review, risk management audit and economic benefit audit to evaluate the economic and effectiveness of the company's resource utilization, and prevent and resolve operational risks. The feasibility and effectiveness of the measures to improve the management level of enterprises. To this end, we should also carry out the reform of audit experiment teaching, adapt to the needs of talents in the development of the times, connect and integrate ERP sandbox and ERP audit experiments, and pass the ERP audit experiment teaching on the basis of the students familiar with the whole 
process of enterprise operation. The audit analysis finds the risks in the operation process, evaluates the economics, efficiency and efficiency of business activities, helps enterprises improve their management and management, improves economic efficiency, and cultivates risk-conscious enterprise management personnel for modern enterprises.

\subsection{The ERP sand table simulation experiment and the ERP audit experiment have the same} goal.

ERP sand table simulation through the dynamic simulation of business activities, the enterprise resources of the upstream and downstream of the enterprise are abstracted on the sand table, so that students can organize the production of the enterprise reasonably, and promote the maximum economic benefit at the lowest cost, and realize the fierce market competition. If you make decisions, organize operations and manage risks, and gain a full range of work experience in running a business, the experimental course allows students to complete the virtual company's five-year annual report, provide continuous and detailed audit data for the audit, and build a simulation enterprise. A five-year simulated auditing environment.

The ERP audit experiment is to use the audit software to review, analyze and evaluate the economics, efficiency and effectiveness of the economic activities of the enterprise, and propose improved opinions and suggestions, including evaluating the strategic objectives and completion of the plan, and the achievements of the enterprise. And the gap, the reasons for analyzing the problem, clear direction for further improving the economic benefits of enterprises. Let students understand and be familiar with the internal audit process and methods, and deeply understand the important role of internal audit in business management.

It can be seen that the two are consistent in the goal of the experiment. They all use simulation teaching to let students understand and participate in all aspects of enterprise management to achieve corporate goals.

\subsection{The ERP sandbox simulation experiment provides a personalized case and audit environment for ERP audit experiments.}

The ERP sandbox simulation experiment divides the students into several groups, which forms a personalized and vivid case of several business operations. If you can record the strategic objectives of the company's five-year management after each complete ERP sandbox simulation experiment, Planning, business process problems and strategies, this will accumulate a series of rich teaching cases for ERP audit experiments, and then apply these cases in the subsequent internal audit courses, but also solve the boring course theory, lack of teaching cases, etc. problem. In the ERP audit experiment, students have a clear understanding of their own business environment, paving the way for risk assessment in the risk-oriented audit process, and can evaluate the gains and losses of their own business through the audit analysis of their own enterprises. Improve the strategy and value-added space, complete the internal audit plan, audit implementation, communication and report audit process. You can also experience internal audit as a functional department within the company, how to play its supervisory role, and add value to the enterprise. Providing services, while improving the attractiveness of auditing teaching, maximizes the enthusiasm and initiative of students to learn auditing.

\section{The integration path of ERP sand table simulation experiment and ERP audit experiment teaching}

\subsection{Adding an audit role to the ERP sandbox simulation experiment}

The primary part of the ERP sand table simulation is to set up the enterprise, group all the students, each group of seven people, complete the enterprise naming, determine the business purpose and business philosophy of the enterprise, conduct the role division, and clarify the job responsibilities of each role of each enterprise. 
Table $1 \times \times$ Corporate staffing and division of responsibilities

\begin{tabular}{l|l}
\hline Character & \multicolumn{1}{c}{ The division of responsibilities } \\
\hline General manager & Develop corporate strategic goals and plans, make decisions \\
\hline Audit director & $\begin{array}{l}\text { Establish an internal control system and risk management system and } \\
\text { strengthen supervision }\end{array}$ \\
\hline financial director & Fund raising and use, report preparation \\
\hline $\begin{array}{l}\text { Marketing } \\
\text { director }\end{array}$ & Market research, analyze the market, ensure sales \\
\hline $\begin{array}{l}\text { production } \\
\text { manager }\end{array}$ & $\begin{array}{l}\text { Propose a production line construction plan, arrange and organize } \\
\text { production }\end{array}$ \\
\hline $\begin{array}{l}\text { Purchasing } \\
\text { Director }\end{array}$ & Develop material procurement plans, purchase materials \\
\hline
\end{tabular}

\subsection{Do the decision record and archive of the ERP sandbox simulation experiment}

Enterprise members of each group are required to submit electronic version of the strategic analysis report, annual business decisions and their implementation, which is a re-summary of the annual business management process, and provides vivid and intuitive case resources for ERP audit experiments. The secondary development of the ERP sand table simulation was completed, and the analysis report is shown in Table 2. The teacher guides the students to complete the one-year simulation run of the enterprise, and allows the students to master the ERP sandbox management rules and procedures, and strengthen the experience of each role division of labor.

Table $2 \times \times$ Product strategic goals and plans

\begin{tabular}{c|c|c|c|c|c}
\hline project & $\begin{array}{c}\text { The first } \\
\text { year }\end{array}$ & $\begin{array}{c}\text { The second } \\
\text { year }\end{array}$ & $\begin{array}{c}\text { The third } \\
\text { year }\end{array}$ & $\begin{array}{c}\text { The fourth } \\
\text { year }\end{array}$ & $\begin{array}{c}\text { The fifth } \\
\text { year }\end{array}$ \\
\hline $\begin{array}{c}\text { Product } \\
\text { development }\end{array}$ & & & & & \\
\hline $\begin{array}{c}\text { Market } \\
\text { Development }\end{array}$ & & & & & \\
\hline Advertising & & & & & \\
\hline $\begin{array}{c}\text { sales target } \\
\text { Equipment } \\
\text { renovation }\end{array}$ & & & & & \\
\hline $\begin{array}{c}\text { Fund budget and } \\
\text { fundraising }\end{array}$ & & & & & \\
\hline
\end{tabular}

Table 3 Record of implementation and adjustment of the strategic plan

\begin{tabular}{l|l|l|l|l|l|l}
\hline \multirow{2}{*}{ project } & StrategicRealignment & Annual \\
\cline { 2 - 5 } & $\begin{array}{l}\text { The } \\
\text { reason }\end{array}$ & result & $\begin{array}{l}\text { Results of } \\
\text { operating plan } \\
\text { the }\end{array}$ & problem & $\begin{array}{l}\text { improvement } \\
\text { measures }\end{array}$ \\
\hline $\begin{array}{l}\text { Product } \\
\text { development }\end{array}$ & & & & & \\
\hline $\begin{array}{l}\text { Market } \\
\text { Development }\end{array}$ & & & & & & \\
\hline Advertising & & & & & & \\
\hline Profit target & & & & & & \\
\hline $\begin{array}{l}\text { purchase } \\
\text { ingredients }\end{array}$ & & & & & & \\
\hline $\begin{array}{l}\text { Fund budget and } \\
\text { fundraising }\end{array}$ & & & & & & \\
\hline $\begin{array}{l}\text { Equipment } \\
\text { renewal } \\
\text { transformation }\end{array}$ & & & & & & \\
\hline
\end{tabular}




\subsection{ERP audit simulation experiment process}

\subsubsection{Develop an audit plan.}

Group the auditors, still grouped according to the original ERP sandbox, audited. The object is the content of the simulated enterprise completed by other ERP sandboxes before the audit, including the case resources left by the previous ERP sandbox simulation experiment, the record of the case using the ERP sandbox, and the preparation and adjustment of the strategic objectives and plans of each department. The annual audit plan initially identifies important audit items and outlines the audit direction and audit scope.

\subsubsection{Audit implementation phase}

By understanding the company's strategic goals and plans and adjustments, using the analysis program, compared with the company's previous year's operating results and other companies in the ERP sandbox case, analyze the causes of the anomalies and find the risk points. Common risk points in enterprise management in the ERP sandbox simulation experiment are:

(1) Failure to fully consider the market demand, industry competition and enterprise resource constraints, resulting in the failure of the strategic objectives;

(2) Plans of various departments, Resources can not be coordinated, do not match, can not achieve the optimal allocation of resources, resulting in low operational efficiency;

(3) The strategic objectives of the enterprise can not adapt to the characteristics of the enterprise, advertising selection and production costs are high and scattered, after all, sandbox experiments have access orders The rules lead to the failure of the enterprise strategic plan;

(4) The problem is not timely adjusted, the development of the enterprise is affected, and the bankruptcy of the enterprise is seriously caused.

(5) The fund-raising integration is too high, and the use and distribution of funds are unreasonable.

Then, through measuring the data for important projects, we can find out the main factors affecting economic benefits, propose specific measures in a targeted manner, and measure the economic benefits that can be realized due to the implementation measures, and affirm the good experience. A complete benefit audit must not only have a qualitative assessment, but also a quantitative assessment to provide clear targets and ways to achieve the objectives. It is very important to make an audit record and make a record of the work paper throughout the audit process. Through the record, the audit data can be classified completely and systematically. It is not only the performance of the auditor's ability, but also an important basis for the preparation of the audit report after the audit is over.

\subsubsection{Audit report stage}

After the above-mentioned audit work, a summary report on the objective and notarization of the trial situation should be made. The report should distinguish the primary, secondary, and gradual classification analysis, use the figures and evidence to compare the auditing standards, measure from various angles, evaluate the economic benefits of the unit under review, and make recommendations and improvement measures. In the economic benefit audit report, there are usually suggestions for improving economic efficiency. How are these recommendations implemented, whether they are accepted by the company, and how effective they are, in reality, follow-up audits are required. The role of follow-up audit is not only to urge enterprises to seriously implement audit recommendations, but also to test the conclusions of the audit. Due to the time limit of the ERP sand table and ERP audit experiments, the follow-up audit can only be reserved for the next classmates. Before the audit, it is necessary to read the report written by the previous classmates in order to sum up the experience and improve the audit level.

\section{Conclusion}

(1) The ERP sandbox simulation experiment and the ERP audit experiment course can realize the 
multi-win effect of teaching and learning. It is feasible in the course objectives, course content and specific curriculum arrangement, and also meets the needs of adapting to the development of the times.

(2) It is possible to add the role of auditing in the ERP sandbox simulation experiment, record and archive the ERP sandbox process, provide personalized case and experimental resources for the audit experiment, and effectively integrate the ERP sandbox experiment and the audit experiment.

(3) According to the internal economic benefit theory and the ERP sandbox experiment, understand the process of ERP audit experiment, analyze the audit risk, design the audit procedure, evaluate the economic benefits of the enterprise, make suggestions and improvement measures, and write a report. Do an organic combination of theory and practice.

As for whether the method proposed in this paper can achieve the desired effect in teaching practice, teachers also need to continuously explore and improve in teaching, and put forward new requirements for teachers and students. Teachers need to comprehensively consider the connection between courses, and the relevant courses remind students to keep the integrity and authenticity of the information.

\section{References}

[1] Lingling Zhang. Exploration of ERP Sandbox Simulation Practice Teaching Based on Public Elective Course[J].High Teaching Journal,2016(22):161-163.

[2] Exploration on the Teaching Reform of "Auditing" Based on the Cultivation of Applied Talents [J]. Youliang Lin, Miaomiao Ye, Tang Yi. Heilongjiang Education (Higher Education Research and Evaluation). 2017(08)

[3] Reform and Practice of Teaching Practice and Teaching Research in University Auditing in China [J]. Xiangzhen Xu, Zhenfeng Chen, Lanfei Wu. Chinese CPA. 2013(01)

[4] Discussion on the Construction Path of Auditing Major Based on Application Transformation [J]. Li Zhang, Ziwei Liu. Business Accounting. 2017(06)

[5] Discussion on the Teaching Reform of Auditing Courses in Colleges and Universities [J]. Ying Bian. Times Finance. 2017(12)

[6] Case-oriented auditing course research teaching research [J]. Zhi Dong. Science Teaching Journal (early issue). 2017(02) 